\title{
Using Revenues from Indigenous Impact and Benefit Agreements:
}

\author{
Building Theoretical Insights
}

\author{
Ciaran O'Faircheallaigh
}

\begin{abstract}
In recent years there has been a rapid growth in the number of mining agreements that generate revenues for Aboriginal communities in Northern Canada and North Australia and in the scale of revenues they generate. While a limited number of empirical studies document the impact of agreement revenues in specific cases, there is little by way of theoretical insights that could form the basis for a more systematic analysis of the variables that determine whether outcomes will be positive or negative. Such an analysis is essential, in turn, to support Aboriginal communities in making informed choices regarding the use and management of agreement revenues. The article begins by considering broader theoretical writing on mining revenues, which indicates strongly diverging views regarding their capacity to support social and economic development. It then turns to two of the most extensive bodies of research on use of mining revenues by Indigenous peoples and customary landowners, those dealing with Australia and Papua New Guinea. While much of this research is not explicitly theoretical, it does seek to explain and predict the impact of mineral revenues, and is thus fertile ground on which to start building theoretical insights. The article concludes by identifying key variables that are likely to shape the outcomes of revenues from IBAs, and by highlighting fruitful areas for future research.
\end{abstract}

\section{Introduction}

In thinking about ways of improving benefits of resource development in the North, the issue of revenues from Indigenous impact and benefit agreements (IBAs) is of particular importance. Unlike many other economic flows from resource development (dividends to corporate shareholders, loan payments to banks, payments for mining equipment and supplies, salaries paid to highly skilled and/or fly in /fly out workers), these revenues at least initially accrue in the North. As such they have the potential to contribute to Northern incomes, economic investment and social capital. ${ }^{1}$ In addition revenues are fungible, and can in principle be channelled to uses that are a priority for Indigenous people and which may not, unlike for example wage employment in mining, require some acceptance of social and cultural norms of the dominant society. In the Canadian and Australian North, mining revenues have been used, for instance, to support establishment or re-establishment of settlements on ancestral lands; cultural activities and transmission of cultural knowledge; and Indigenous management of lands and resources (Gibson MacDonald, Zoe and Satterfield 2014, 68-73; O’Faircheallaigh 2010). There are other less positive reasons why a focus on revenues from IBAs is important. Payments to Indigenous communities can also have negative impacts, for example by causing social conflict and enmity; where they are used to support socially destructive behaviour such as excessive alcohol consumption; or where their availability discourages traditional economic activity (O’Faircheallaigh 2002: 153-79; York 1990: 88-106).

Related to these points, if an IBA generates revenues, their use and so their impact will be determined through public governance systems. This is not to assume that such systems will necessarily be democratic or focused on the (Indigenous) 'public good'. Rather the point is that a focus on revenues from IBAs of necessity involves a focus on Indigenous 
governance, an issue which has critical ramifications for the impact of resource development in the North.

The purpose of this article is to start building theoretical insights that would help identify key variables that explain outcomes from IBA revenues, and so provide a sound foundation on which Aboriginal communities can adopt policies and develop management structures likely to enhance the positive impacts of revenues while avoiding or mitigating their negative effects. It begins by considering broader theoretical writing on mining revenues. Much of this addresses arguments regarding the so-called 'resource curse' which suggests that mining revenues are inherently inimical to development. The article then turns to the most extensive body of empirical research on use of mining revenues by Indigenous peoples and customary landowners, writing on Australia and Papua New Guinea in the period since the late 1980s. While often not couched in explicitly theoretical terms, this research does seek to explain and predict the impact of mineral revenues and so can offer theoretical insights that are potentially applicable in other contexts. The article concludes by identifying key variables that are likely to shape the outcomes of revenues from IBAs and whose operation can be influenced by implementation of appropriate policies and institutional arrangements. It also suggests areas where additional research is needed to further advance theory building.

\section{The 'resource curse'}

The 'resource curse' literature argues that public revenues generated by mining have strongly negative impacts on economic, social and political development and that this is inevitably so. The cyclical character of global commodity markets can result in sharp fluctuations in mineral prices and so in revenues for governments and communities, resulting in an inability to accumulate sufficient funds to finance major investments or service loans, or to maintain community and social infrastructure funded from mining revenues. Fluctuating revenues can also create major obstacles to effective community planning (Alexander and Gilbert 2010, 48). The availability of mining revenues, especially where large and unexpected flows occur because of sharp mineral price increases, may create a false sense of prosperity, undermining prudent financial management and careful planning in organisations and communities. It can encourage and mask wasteful behaviour, discourage efficiency and innovation, and give rise to growth of inefficient bureaucracy (Bucuane and Mulder 2007; Sovacool 2010).

While some of these result from the effect of mineral revenues on exchange rates and wage levels at the level of national economies and so are not applicable to Indigenous communities, a key aspect of resource curse theories focuses on behavioural, institutional and political responses to mining revenues, which are equally relevant at the community level (Ross 1999, 308-319; Huskey this volume; Southcott and Natcher this volume). When prices and revenues are high, political leaders may be under pressure to increase spending and embark on major capital projects, and when prices decline it may be hard to rein in spending to match the available revenue (Sovacool 2010, 230). Access to mining revenues may diminish the incentives to save to fund investment, by creating the impression that current and future wealth will be generated by mining (Bucuane and Mulder 2007, 18-19). Only the creation of mechanisms that guarantee saving and investment of an appropriate portion of mineral revenues as they accrue can address these issues (Eggert 2001, 45).

Many resource curse theorists argue that such an outcome is unlikely because of what they characterise as 'rent seeking', that is a preoccupation with appropriating existing mineral revenues for immediate consumption, rather than engaging in productive activity that can generate additional economic and social benefits. This diversion of talent and effort from productive enterprise may not only result in short-term economic and social opportunity 
costs, but eventually create a culture and an institutional landscape that undermines a community's capacity to innovate and generate new opportunities. Mining revenues may be particularly prone to cause rent seeking because of their high visibility, reflecting the degree of public attention generated by new mining projects and associated decision making processes; and a perception that the amount of money involved is substantial and so likely to reward the efforts of rent seekers (Karl 1997; Robinson et al. 2006; Huskey this volume).

Rent seeking does not of itself necessarily deprive communities of the benefits of mining revenues. However it can degenerate into corruption, so that people in positions of power begin to enter into arrangements with mining companies that allow the individuals concerned to appropriate mineral revenues, in return for their support for decisions that favour mining companies (Siakwah 2017: 129-30). This may not only deprive local communities of benefits, but also result in serious harm where mining companies corruptly obtain approval from decision makers for activities that create environmental and social damage.

As the discussion of rent-seeking illustrates, some resource curse theorists do afford institutions and public policies an important role in their analysis. However they do not regard them as independent, causal variables, but rather as themselves being shaped by the existence of extractive industries and mineral revenues, rather than shaping the impact of mining and the way in which revenues are used (Sandbu 2006, 1155-56; Williams 2011). For example Pegg (2006, 379) argues that resource dependence shapes the nature of institutions and public policies, and concludes that 'capital intensive natural resource industries are a major determinant of corruption'. Similarly, Sachs and Warner $(1997,23)$ found that 'resource abundant [developing] countries have poorer scores on a variety of measures of institutional quality'. Alexander and Gilbert (2010, 33-34) note that even where appropriate policies and institutional arrangements are initially put in place, they are often quickly abandoned because of the incentives politicians face to divert resource revenues for their own purposes (2010, 33-34; see also Karl 1997).

\section{Variable outcomes and the role of institutions and policies}

A second set of theories argues that the impact of mineral revenues on local, regional and national economies is determined not by the inherent characteristics of those revenues but by the institutional and policy framework within which they are received and managed. This approach wins support from large-scale statistical studies and comparative case study work suggesting that the empirical evidence for the existence of a resource curse is far from clear, and in particular that there is no inevitability that mineral revenues will have negative implications for development. For example Brunnschweiler and Bulte (2008), synthesising a wide array of empirical studies, state that although there are individual countries where dependence on mining is associated with poverty and has eroded institutions, resource riches can be associated with high incomes and robust institutions (Brunnschweiler and Bulte, 2008: 617). Collier and Venables (2011) in a comparative study of mineral-dependent economies document a wide variety of outcomes, including between different nation states (Chile and Cameroon), the same state under different policy regimes (Zambia, 1969-2000 versus 2000-2008), and between pairs of Nigerian provinces that are similar in terms of their engagement with the oil industry (see also Eggert, 2001; Stevens, 2003; Mehlun et al., 2006; Pegg, 2006; Robinson et al., 2006; Sovacool, 2010; Huskey this volume; Rodon this volume).

A number of studies, conducted in a range of historical and geographical situations, indicate that the policy and institutional context is critical in explaining this variation in outcomes. For example Robinson et al. (2006) note that resource booms create incentives for 
politicians to use mineral revenues to buy votes, especially through the generation of public sector employment. Behaviour of this sort accounts for what is often identified in the literature as 'policy mistakes' or wasteful use of resources. In their view it rather reflects rational responses to political incentives, and the extent to which these 'political incentives map into policy outcomes' depends on the quality of institutions in the country concerned (2006: 447-48; see also Sandbu, 2006: 1153-54; Bucuane and Muller, 2007: 20-21). Clark (1999: 15-16) notes that particular problems in relation to institutional capacity and implementation skills may arise at the local level, in part because governments tend to allocate skilled personnel to politically-sensitive regions, which may not be those where extractive industries are located (see also Haselip, 2011).

One issue that attracts little explicit focus in the literature involves political leadership. The role of elites does attract considerable attention in the resource curse literature, with their tendency to engage in rent-seeking or corrupt behaviour often offered as one explanation for the failure to put mining revenues to good effect (Stevens, 2003: 14; Alexander and Gilbert, 2010: 9-10). But the potentially positive role of political leadership in developing appropriate policies and institutions and so in bringing about favourable outcomes receives little attention (for exceptions see Stevens, 2003: 16-17; Alexander and Gilbert, 2010: 15). In fact, it is possible that leaders could play a critical role, for example by raising people's horizons beyond the short-term, individual benefits represented by rent seeking, and in developing the organizational capacity to use mineral revenues productively (Altman and Smith, 1994; O’Faircheallaigh 2002).

More broadly, while highlighting the importance of institutions, the literature is less helpful in identifying the specific types of institutional structures and capacities that are likely to maximise benefits from extractive industries and, particularly, how these might be developed. For example neither Mehlun et al. (2006) nor Robinson et al. (2006) specify what sort of institutional change is required to enhance the 'quality of institutions', or how this might be effected. Other authors are more specific about institutional requirements, emphasising for example the need for them to operate according to rules that are simple and explicit and to have clear mandates and jurisdictions so as to enhance transparency and accountability. But they do not discuss how this might be achieved (Eggert, 2001: 65-66; Bucuane and Muller, 2007; Williams, 2011).

\section{Perspectives on Aboriginal Australia}

\section{Explaining specific outcomes}

The Australian literature does not tend to focus on general theoretical insights that might explain outcomes from Aboriginal mineral revenues. Much of it is orientated towards policy debates regarding the character of such payments and the rationale for making them, and on the related issue of how such payments should be employed. In addition, there is a substantial literature that documents outcomes in relation to payments from specific mining projects. In some cases an attempt is made to explain outcomes in relation to the projects concerned and, while such attempts may not be explicitly theoretical, they often have wider implications in terms of explaining and predicting the likely impact of mineral revenues. They are thus of interest in considering potential conceptual frameworks for analysis of revenues from IBAs.

One example involves Robert Levitus's research on royalty payments from the Ranger uranium mine in the Western Arnhem Land region of Australia's Northern Territory, and on the history of the Gagudju Association, which received these payments for nearly two decades after the establishment of the project. Gagudju initially enjoyed considerable success 
in bringing together disparate Aboriginal groups connected to land used by Ranger or otherwise affected by its development, and for more than a decade after mining commenced in 1981 used royalty payments mainly to fund community infrastructure and business enterprises, with small, identical cash payments being made to adult members and placed in trust for children. However Gagudju ran into difficulties in the mid-1990s and eventually collapsed, being replaced by the Gunjehmi Association, whose membership was much more narrowly focused on the traditional owners of the Ranger mine site.

Levitus attributes Gagudju's decline to the difficulty of maintaining an 'umbrella' body that sought to bring together disparate Aboriginal interest; to an underlying failure to apply systematic and consistent criteria in identifying areas affected by Ranger and in defining eligibility for membership of Gagudju; and to a series of specific and contextual factors. The latter included tensions among association members over allocation of funds to investment rather than cash distributions and generational leadership change, with a younger generation lacking the wider social networks that had helped maintain Gagudju. They also included a rapid fall in royalty income due to falling uranium prices that undermined Gagudju's ability to service its business loans while maintaining community infrastructure and individual payments; and tensions with the regional Aboriginal land organisation, the Northern Land Council ${ }^{2}$, regarding negotiations with the Commonwealth for an amended agreement for the Ranger mine. At a broader level, Levitus also drew attention to the tensions inherent in seeking to reconcile the statutory provisions of a legal instrument developed within a European legal framework (the Aboriginal Land Rights (Northern Territory) Act 1976), and Aboriginal cultural and social imperatives (Levitus 1991, 2005, 2009).

Some of these factors are clearly of wider relevance, for example the negative impacts of falling royalty income, which resonates with the resource curse literature, and the absence of clear eligibility criteria, which Eggert (2001) identifies as one key component of an appropriate policy framework for managing mineral revenues. Perhaps more fundamental is the tension Levitus notes between the needs and interests of Aboriginal traditional owners closely associated with land on which mining occurs, and those of wider social groups which share social and cultural links to those traditional owners and which are affected by the wider social and cultural impacts of large mining projects. As Stanner notes (2009, 151-52)

Aboriginal peoples have traditionally had multiple cultural and social connections which they continue to mobilise, or seek to mobilise, as their social and economic circumstances change. In this context it seems likely that the way in which this tension between the narrower interests of specific landowner groups and the demands and opportunities represented by the wider social and cultural networks within which they are located is likely to be critical in determining the outcomes of mineral revenues.

O'Faircheallaigh (2002) has also focused on the Ranger experience, but in the comparative context offered by the development, in the same period and only some $50 \mathrm{~km}$ away, of the Nabarlek uranium mine. He sought to explain the quite different outcomes generated by Ranger and Nabarlek over the period between the late 1970s and 1995, during which time Nabarlek payments, in contrast to those from Ranger, failed to generate significant community development initiatives or successful business investments. In Gagudju's case, positive factors included that the Association was established for some years before it received substantial revenues, allowing it to get its operations on a sound footing before it had to deal with large amounts of money. Expenditure patterns and priorities were set at annual general meetings that attracted large numbers of members and provided a degree of transparency and accountability. Very importantly, Gagudju displayed a substantial capacity for autonomous action in pursuit of its own objectives. It operated independently of the mining company that generated most of its revenues, and indeed maintained a distinctly ‘arms length’ relationship with Ranger Uranium Mines, reflecting in part earlier opposition 
by traditional owners to the establishment of the Ranger project. It also operated independently of the Northern Land Council and of government agencies, though it was happy to accept government funding as long as this accorded with its own priorities.

As with Levitus's analysis, some of these factors (for example the timing of Gagudju's formation) are specific and contextual. Others have wider ramifications, in particular the ability to achieve transparency and accountability while at the same time maintaining cultural integrity and the autonomy to pursue Aboriginal interests, which appears fundamental to Gagudju’s success.

Critical factors in explaining the less positive outcomes from the Nabarlek project include delays in the formation of an Aboriginal incorporated association, Kunwinjku, to receive royalties. This did not occur until two years after substantial income started to flow from Nabarlek. Prior to Kunwinjku's formation financial benefits were distributed in an ad hoc fashion, tended to reflect the influence of politically-skilled Aboriginal people, and involved allocation of substantial sums in cash, and of vehicles, to individuals or small groups. This pattern of allocation proved impossible to break once the Kunwinjku Association was formed, in part because membership of the Association was defined very broadly, on the basis of residence of a wide area deemed to be affected by the Nabarlek mine. This allowed opportunities for politically-ambitious people who were not traditional owners for Nabarlek to play a major role in Kunwinjku's affairs. The Kunwinjku Association's constitution and organisational structure were highly complex and lacked transparency. Combined with the fact that the Association's office was based in Darwin rather than in Western Arnhem Land, this made it very difficult for traditional owners to keep themselves informed about what was happening and to hold Association officials accountable (O’Faircheallaigh 2002).

Here also some of the factors involved are specific and contextual (for example the timing of Kunwinjku's formation), but as with Gagudju others have wider relevance. In particular, the issue of 'narrow' versus 'broad' definition of beneficiary groups and of the management of tension between these appears fundamental, with Kunwinjku suffering from an approach that heavily favoured a 'wide' definition. The issues of transparency and of institutional design and capacity resonate with the critique of the 'resource curse' literature that suggests that 'institutional quality' is fundamental in shaping outcomes.

\section{Aboriginal culture and mineral revenues}

In addition to research dealing specifically with mineral revenues there is a broader literature on resource allocation and related cultural and social practices in Aboriginal Australia that are potentially relevant in explaining outcomes from such revenues. Examples include Peterson's work on demand sharing, the practice of demanding that relatives or socially related individuals display generosity and share material goods or cash with those making the demand. As Peterson notes (1997, 189-90) demand sharing is often condemned by nonIndigenous people because it conflicts with Western views of generosity as equated 'with unsolicited giving', and sees 'demand sharing in negative terms and as purely self-interested'. Demand sharing is also criticised as freeloading or parasitic behaviour by the lazy and manipulative which can remove the incentive for Aboriginal people subject to such demands to undertake wage employment or business ventures, because the fruits of their efforts will largely be appropriated by others (Peterson 1997; Trigger 2005, 47-53).

In the context of mineral revenues demand sharing could be seen as likely to contribute to dissipation of payments and their allocation to consumption rather than to investment in social capital, for example through education of children or establishment of businesses, and also as subjecting individual beneficiaries to harassment and even to violence 
at the hands of disappointed 'demand sharers'. However Peterson $(1997,190)$ argues that demand sharing can also be seen in a positive light, for instance:

as testing behaviour to establish the state of a relationship in social systems where such relationship[s] have to be constantly produced and maintained by social action, and cannot be taken for granted... It may be a substantiating behaviour to make people recognising the demander's rights. And paradoxically, a demand in the context of an egalitarian society can also be a gift: it freely creates a status asymmetry, albeit of varying duration and significance.

This raises the possibility that demand sharing could serve to spread the benefits of mineral revenues and at the same time reinforce social relations that might otherwise be strained by the inequalities potentially created by a situation in which some individuals receive payments and others do not. More broadly, any approach that fails to recognise the relevance of social relations to the way in which mineral revenues are distributed and used, and the manner in which decisions about these matters are made, is likely to create significant social tension.

The discussion of demand sharing and kinship raises the wider issue of whether elements of Aboriginal culture and society are inherently inimical to success in commercial enterprise and generally in participating in the market economy. If this were true, it would not necessarily mean that mineral revenues were unlikely to generate positive impacts, as they could be used to support traditional cultural and social activities. However a different situation would exist if Aboriginal recipients saw mining revenues as a platform on which to build substantial engagement in the mainstream economy.

Trigger (2005, 46-51) cites a range of authors who identify the following cultural traits or practices as obstacles to Aboriginal involvement or success in market activities: demand sharing of resources; the pervasive importance of kinship and pursuit of family loyalties; the communal ownership of assets like land and the tension this creates with private enterprise; a high stress on personal autonomy; resistance to delegating authority; internecine feuding; accusations of sorcery; an ethic of egalitarianism that might be regarded as counter to individual achievement; politicking around powerful personalities; rejection of material accumulation as an idea; and a commitment to continuity with the past that is antithetical to innovation.

The work reviewed by Trigger appears to ignore the important issue of the direction of causality between cultural practice and economic opportunity. Some of the cultural practices Trigger summarises may be a protective reaction to severe economic deprivation, and may diminish in their impact as Aboriginal people gain access to economic opportunities, rather than acting as an impediment to realisation of those opportunities. In addition, As Trigger notes $(2005,52)$ some of these factors, for example webs of familial and social relatedness, are not necessarily antithetical to economic success, and indeed in other cultural contexts (for instance certain immigrant populations) have indeed been central to such success. Nevertheless, Trigger argues that at a general level 'new ways must be found of articulating market participation with a number of key Indigenous values' $(2005,55)$.

Other authors begin by accepting what they regard as realities of the Aboriginal social and cultural milieu, and argue that organisational structures and processes need to adapt to these. For example Martin and Finlayson (1996) emphasise the importance of kinship and localism in Aboriginal society and politics, and the need to acknowledge this point in designing organisations to receive income from mining projects which create impacts across wide regions (see also Mantziaris and Martin 2000, 282-3). For instance if local groups do not feel adequately represented and if they feel that decisions affecting them are being made 
in forums in which they have little influence, they are likely to break away and form a new and rival organisation which can engender conflict and dissipate resources.

Yet at the same time, 'even in the most segmented and individualistic of indigenous societies, locally based relations to land and water must be understood as arising within wider based systems of traditional law and custom' (Mantziaris and Martin 2000, 283). In addition, many modern mining projects are on such a scale that they generate impacts and opportunities that are regional rather than local in scope, and effective responses to them require organisational responses that are regional rather than exclusively local. The ability to balance and manage local and regional interests thus becomes a critical aspect of institutional capacity (Mantziaris and Martin 2000, 283-4). Here also there is a strong resonance with the emphasis in the 'institutional quality' literature on the importance of institutional design in shaping outcomes from mining revenues.

Another body of work involves the nature and structure of Aboriginal interests in land and resources. A critical point in this regard is that these interests are different to the singular, well defined interests in land typical of Western land systems. For example, in freehold land in Australia and Canada only one entity, whether individual or corporate, holds an interest in the land concerned, and it holds all of the interests that exist in that land, subject to standard reservations on behalf of the Crown (typically, sub-surface minerals, and the right to compulsorily acquire land for public purposes). Aboriginal interests on the other hand tend to be layered, complex, differentiated and hierarchical, and to give rise to, and also reflect, sets of social relationships, not just property or economic relationships. As Bauman notes (2005, 8) Aboriginal rights and interests:

might accrue through patri- and matri-filial inheritance to country, for example, through ritual responsibilities clearly defined through the travels of mythical ancestors, or through being born at particular places and so on ... they do not fit within neatly bounded apparently homogenous groups ... at least some Indigenous rights and interests should be viewed as contextual and negotiable amongst Indigenous parties themselves.

Bauman $(2005,2006)$ also stresses the importance of ensuring that structures and processes are in place to identify and manage conflict between the multiple interests that exist in land and resources, and regards the absence or inadequacy of such structures and processes as a major cause of negative impacts generated by mineral revenues and as likely, in itself, to result in further escalation of conflict. Again, this point resonates with the 'institutional quality' literature.

The clear implication of this discussion is that distribution arrangements for mineral revenues, reflecting the nature of Aboriginal rights and interests in land, also need to be complex and differentiated. Failure to achieve this is likely to result in social conflict and potentially in litigation and loss of the potential benefits associated with those payments.

\section{Institutional and organisational design}

Another area of research that is clearly relevant to outcome from mineral revenues, and one touched on above in discussing the need to reconcile local and regional interests, involves design and management of Aboriginal organisations. Levitus (2009), in an analysis that relates a wider discussion of institutional characteristics to the specific context of organisations that receive mineral revenues, identifies four 'structural conditions' affecting the capacity of Aboriginal organisations to effect developmental change on behalf of an Aboriginal constituency $(2009,75)$. The first involves the design of the organisation, that is 
the geographical area, functions, population and other organisations it will encompass. Organisations may correspond in this regard to a local Aboriginal group, but higher levels of Aboriginal organisations may also emerge, as a result of legislative recognition of Aboriginal rights at state/provincial, territory or national levels. The relationship between an organisation and its corresponding 'Aboriginal domain' is dynamic, for example because resources flowing through an organisation have a capacity to reconfigure that domain (Levitus 2009, 78).

The second condition relates to the manner in which financial resources flow to an organisation and the extent and nature of the oversight of funds paid to it, including the issue of public accountability, which can place Aboriginal organisations in a mediating role between external accountability requirements and internal cultural conventions (Levitus 2009, 79). The third condition involves 'the extent to which an organisation is able to [provide] ... a protective layer that intercedes between the Aboriginal domain and the outside world ... and creates interior space for the formulation of Aboriginal priorities and responses'. An organisation's ability to do so will be affected by the availability of other organisations that can provide similar services and the scope that individuals and families have to conduct their affairs through these organisations (Levitus 2009, 83).

The final condition involves the internal coherence and integrity of the Aboriginal domains an organisation represents. Levitus notes that disputes among native title or land right claimants, family politics, disquiet over the creation of artificial 'communities' or the legitimacy of representatives can all go to subvert internal coherence (2009, 85; see also Mantziaris and Martin 2000, 266-67, 277-81). In this regard he discusses Von Sturmer's analysis of the impact of uranium royalties in Western Arnhem Land, which stresses the way in which establishment of royalty associations represented opportunities for Aboriginal people to pursue personal advantage rather than act 'as protagonists on behalf of an agreed community conception of welfare’ (Levitus 2009, 85-89).

In considering the relevance of these 'conditions' to the mining industry, in relation to the first Levitus notes the industry's tendency to concentrate flows of resources to Aboriginal interests at a local level to protect its social licence to operate, and so to organisations 'constituted within limits that are proximate to the extraction project itself' $(2009,91)$. The mode of transfer of resources tends to be relatively free and to organisations under the control of local traditional owners, a situation Levitus notes diverges from the growing tendency for government funding for Aboriginal organisations to be accompanied by specific spending prescriptions. In relation to the third condition (the availability of alternative service providers) he notes that the significance of mining revenues is ambivalent. On the one hand they provide substantial additional income which can enhance an organisation's ability to meet its constituents' needs for social development, but at the same time mining projects tend to result in development of new services and infrastructure which can generate alternative sources of services for Aboriginal people. Finally, on the issue of internal coherence, organisations established to receive mineral revenues often have constituencies that reflect accidents of geology and project location in relation to existing settlements. As a result they can be characterised by 'the absence of any "natural" constituency and therefore of any original legitimacy' and so are 'unusually predisposed' to 'political fission' (Levitus 2009, 90 $-92)$.

Levitus does not use this analysis to stipulate an 'ideal' set of 'conditions' which would maximise the capacity of organisation that receive mineral revenues to contribute to Aboriginal development. However it seems evident that such a capacity would certainly require the ability to create and maintain a 'space for the formulation of Aboriginal priorities', and to achieve a substantial degree of 'internal coherence' while at the same time reflecting shifts in the internal political dynamic of an organisation's constituency. More 
broadly, Levitus's analysis can provide a useful framework within which to examine and help explain the experiences of organisations receiving mineral revenues.

The issues of institutional design and of culture, discussed earlier, come together in the work of the Harvard Project on American Indian Economic Development. Based on a comparative review of the economic development record of a number of tribal governments, Stephen Cornell and his colleagues concluded that critical elements in successful economic development were not their natural resource endowment, education levels or access to capital, but rather how nations are organised, make decisions and govern themselves. Of particular importance in this latter regard is 'sovereignty', or control over their own affairs; effective governing institutions; and the 'match', or lack of match, between specific Indian cultural values and practices and the organisational forms used by tribes to pursue economic development. Governing institutions have to match indigenous ideas about how authority should be organised and exercised, and institutions must match contemporary indigenous cultures if they are to be effective. For example, Connell and Kalt cite the contrast between Apache and Sioux communities in the US. The Apache used organisational structures and decision making methods that aligned with their cultural values and in particular their emphasis on strong, centralised decision making and leadership. The Sioux on the other hand achieved no such congruence between cultural values and organisational form, a fact to which Cornell attributes their failure to achieve economic success (Cornell and Kalt 1995; and more generally Cornell and Kalt 1998, 2010; and Rodon this volume).

The Harvard Project's approach has been adopted by some analysts in Australia (see for example Dodson and Smith 2003, 9-19), but has also come under substantial criticism. Sullivan argues that the Project's conclusions are not supported by its empirical research; that the Project fails to provide any guide for action if there is an absence of 'cultural match' or if culture is positively inimical to economic development; and that, if applied to the Australian context, it ignores the fact that much of the land that Aboriginal people have been allowed to retain, or to claim, has little economic potential, a major obstacle to economic success regardless of the mode of governance adopted (Sullivan 2007, 5-11). Mantziaris and Martin (2000, 293-94) argue that 'the complexity and diversity of contemporary indigenous cultures do not allow for reference to a homogenous and historically prior notion of "culture" that would assist in the formulation of institutional rules and practices'. They also make the point (2000, 324) that contemporary Indigenous institutions have to operate in an intercultural sphere, and that given this reality aligning institutional arrangements with what is 'culturally appropriate' will not achieve organisational effectiveness or legitimacy (see also Altman and Pollock 1998b, 33-34). This point is certainly relevant in the context of organisations that manage mineral revenues, which must for example engage effectively with non-Indigenous organisations and individuals such as mining companies, financial institutions, investment advisers and potential business partners as well as with their own Indigenous constituency.

On the other hand the literature is replete with examples of the problems caused when non-Indigenous institutional forms are foisted on Aboriginal peoples (see for example Kesteven 1984, 144-48; Altman and Smith 1994, 1999; O’Faircheallaigh 2002). Against this background Altman and Pollock argue (1998, 33-34) that those organisations that draw on both the Aboriginal and non-Aboriginal domain in creating structures and processes to manage mineral revenues are likely to be most effective. A critical issue, of course is how this integration of the two domains can be effected.

\section{Mineral revenues and customary landowners in Papua New Guinea}

There is a large and rich body of writing on mining revenues and customary landowners in Papua New Guinea (PNG). This reflects the substantial focus of Australian academics on 
PNG; the fact that the large scale of PNG's mining and oil and gas industries combined with the central role of customary landowners in PNG politics have resulted in large flows of money from mining projects to landowners; and that a number of PNG projects have resulted in major conflicts between landowners and developers and among landowners. One such project was the Bougainville copper mine at Panguna, which led to an armed rebellion in 1989, the permanent forced closure of what was one of the world's largest copper mines, and a protracted civil war.

While the sources of the Bougainville conflict are complex, there is widespread agreement that compensation and other payments to customary landowners played a part in its genesis. Filer (1990) argues that it played a central part, and that conflict was indeed inevitable because of a fundamental incompatibility between large-scale mining revenues and the social structures available to Melanesian societies to manage them, an argument Filer labelled 'social disintegration theory'. The delineation of communal land into individual blocks and the failure of some individuals nominated as 'blockholders' to distribute occupation fees and compensation payments more widely led to problems of social stratification, inheritance and succession within landholder communities, and eventually led a new generation of landowners to close the mine. This outcome did not simply reflect the greed of certain individuals, but 'the simple absence of a custom which prescribes the proper way to distribute rent' (1990, 12; see also Bainton 2010, 193-94). In Filer's view increasing the flow of payments to landowners would simply exacerbate the problem and bring forward the point at which the (inevitable) social conflict would occur.

Filer's position has come under criticism, both on the basis that the Bougainville conflict in reality resulted from a combination of massive environmental damage and the low level of payments to affected landowners and other affected Bougainvilleans; and on the grounds that other mines in PNG have not replicated Bougainville's experience, as Filer predicted they should (Filer 1990; O’Faircheallaigh 1990; Banks 1996, 233-34). However if Filer is correct, then one might expect to see similar problems arise in other contexts where mineral revenues are made in a cross-cultural context, including Aboriginal Australia and northern Canada.

What appears beyond doubt from the PNG literature is that the effects of mineral revenues are greatly influenced by the specific cultural and social forms that characterise customary landowner societies, and that those forms are in turn shaped by mineral revenues. However the nature of that interaction is complex and difficult to predict, and whether or not the outcomes should be regarded as positive or negative involves questions of judgment.

A number of authors argue that the interaction of mineral revenues with existing social reforms creates negative impacts, including by sharpening social inequality. For example the tendency for men to dominate public decision-making processes, including interactions with mining companies and government agencies (themselves male dominated) can result in women being marginalised and failing to share in the economic benefits of mining. The replacement in feasts of food grown by women with food purchased from mineral revenues can further reduce their influence. At the same time women often bear the burdens associated with resettlement and/or loss of land often associated with large mining projects. The net result can be a sharp increase in gender inequality (Bainton 2010, 131-37; Gilberthorpe 2007).

Women are by not always passive recipients of the impacts of mining revenues. Where they have a say in revenue use, they are consistently reported as being more concerned about the future than men, less inclined than men to treat mineral revenues as a source of 'ephemeral cash', and more likely to favour allocation of funds to family needs and community development initiatives (see for example Macintyre and Foale 2007; for similar findings in an Australian context, see Hunt 2005). 
Mineral revenues can have other effects on social relations. Bainton (2010), for example, argues that on Lihir mineral revenues have not lead to a loss of culture but have resulted in quite profound changes to cultural practices and social values. The arrival of 'cash' has affecting the way in which ceremonies are conducted, has led some men to try and narrow the circle of their customary social obligations, changed attitudes to 'outsiders' and to relationships in families. In relation to the last, some men have attempted to channel wealth solely to their children, denying previously strong links between maternal uncles and nephews/nieces, for instance (for other examples of similar responses see Haley and May 2007; Gilberthorpe 2007, 2013, 475).

However there is evidence that in in some contexts customary cultural and social forms can be used to spread the benefits of mining and thus minimise or limit tendencies to social inequality and conflict. For example Biersack (1999) found that the Ipili people of the Porgera Valley invited individuals from groups with whom they have historically had reciprocal social and economic relations to reside in the area of a mining project, allowing them to share in mineral revenues and other benefits. Traditionally, Ipili society was open, porous, and flexible, with an emphasis on creating as many social connections as possible because these could be drawn on for example in periods of food shortage or when escaping from family problems or war. Biersack states that while the Ipili complained about 'outsiders' moving onto their land and seeking to benefit from mining, the Ipili were often complicit in their presence and in some cases had invited them in. She also noted $(1999,274)$ that payment of bride price from mineral revenues allowed these to be spread away from the identified landowner group for the mine, an outcome not intended by the mining company or government but one that can may in fact reduce social tension (see also Banks 1999). The wider circulation of money that results from Ipili social and cultural mores may also help the Ipili build social capital and so generate long-term benefits. According to Biersack (1999, 278): 'Today, as before, marriage and hospitality are used to build and exercise networks, but the effort is specifically to undercut any polarisation of rich and poor which mining might create'.

It should be noted that such an outcome has emerged in a situation where payments are made in cash to landowners, who are then free to apply them as they see fit. These circumstances do not always apply in PNG (nor, it should be noted, in Aboriginal Australia or northern Canada), because mining companies and governments may seek to satisfy themselves that the 'correct' landowners are being compensated, in an attempt both to limit their expenditure and to minimise any opposition to the project. However such an approach can lead companies and governments to insist on demarcation of rigid land boundaries and identification of designated 'landowners' or 'affected communities' in contexts where interests in land were previously multi-layered and flexible in the face of changing demographic, social or ecological circumstances. Such an approach can undermine longstanding socio-political networks and the interactions that ensured social and economic security over wide areas in the recent past, and can result in individuals or groups who have a legitimate interest in land being excluded from mine payments (Banks, 1999; Gilberthorpe and Banks 2012; Sillitoe and Wilson 2003).

Companies and governments may not only disagree with landowners about who should receive payments, but about how those payments should be used. Gilberthorpe, for instance argues that that the desire of the project operator and government agencies to apply a 'community development approach' to use of mineral revenues from Ok Tedi simply does not fit with the approach of local Min people. 'While the state and corporate sector expect cash ... to stimulate community development, locals use it to redefine socio-political power ...' $(2013,478)$. She argues that customary values are not recognised, with the emphasis on 'development projects' failing to acknowledge 'how cultural institutions and individual 
agency inform the way projects are received' $(2013,479)$ This suggests that it may not be the case that customary systems cannot deal with money from mining projects, but rather that they cannot cope with externally-imposed models of how money should be used. Indeed Gilbethorpe and Banks argue that much of the conflict that has surrounded allocation and use of mineral revenues in PNG is avoidable if companies and governments engage with 'the cultures inhabiting the land in which minerals are embedded' and escape from the 'blinkeredness to local trajectories of change and interrelationality that can lead to the kind of mining-imposed disasters seen in Bougainville and Ok Tedi' $(2012,187)$.

One general point on which all researchers agree is that customary landowners in PNG are far from passive recipients of the impacts of mineral revenues. Filer $(1999,9)$ expresses this point by arguing that the analogy of impacts as representing ripples in a pond created by the 'stone' of mineral revenues is inappropriate. He points out that the concept of a big fish swimming in a pond is more apt, as it leaves the possibility that other fish can also create ripples.

\section{Conclusion}

Both the theoretical and applied literatures reviewed above are ambiguous in their implications for the prospects that mineral revenues can contribute to Aboriginal social and economic development. The resource curse literature argues that those prospects are nonexistent, and that the impact of payments is inevitably negative. There is some support in the empirical literature for the view that any inherent tendency for mineral revenues to create negative effects is likely to be exacerbated by Indigenous cultural and social values, priorities and practices. On the other hand there is evidence to suggest that outcomes are not inevitably negative but rather are shaped by the specific institutional structures and decision making processes used to deal with mineral revenues. recognise the distinctive and 'layered' nature of Indigenous or customary rights in land and the dynamic and flexible character of associated social and cultural relationships.

What are the key variables likely to shape the impact of mineral revenues? The empirical literature suggest strongly that a key consideration is to extent to which and the way in which tensions between the narrower interests of the Indigenous 'owners' of land on which a mining project is located, and the wider interests of Indigenous people affected by the project, are managed. Reinforcing the importance of this issue is the need to account for the distinctive and 'layered' nature of Indigenous or customary rights in land, and the dynamic and flexible character of associated social and cultural relationships. A critical issue here is not so much whether there is a broad 'match' between a static 'cultural reality' and 'institutions', as suggested by the Harvard Project, but rather how in specific contexts institutions can be designed that facilitate the positive management of what will inevitably be ongoing sources of tension, complexity and change.

A noticeable feature of much of the literature reviewed is that while it recognises the importance of institutions in shaping the impact of resource revenues, it has little to say about how to develop appropriate institutions if these do not already exist. In the Indigenous context in particular, there is little guidance about how, in practice, institutions can be developed that both reflect Indigenous values and are effective in engaging with large-scale mining projects and the economic opportunities they offer. In this regard there is a need for research on the efforts of Aboriginal groups to develop such institutions and to consider what lessons can be drawn from their experience. One specific focus in this regard should be on the role of leadership in pursuing institutional innovation, an area that, as noted earlier, receives little attention in the wider 'resource curse' literature. 
Another critical variable involves the degree to which there is scope for Indigenous agency and autonomy in the use of mineral revenues vis-à-vis non-Indigenous interests, and the extent to which such 'external' autonomy is combined with a high degree of 'internal' accountability of Indigenous leaders and revenue managers to their Indigenous constituencies. High external autonomy combined with high internal accountability appears to greatly increase the likelihood of positive outcomes. Here also further research is required to establish what explains varying outcomes in this regard and what institutional forms enhance the prospect of positive outcomes.

Finally, specific aspects of Indigenous culture clearly have significant effects on the use and impacts of mineral revenues. The available empirical evidence does not appear to support Filer's argument that social disintegration is the inevitable result when Indigenous cultures encounter mineral revenues. Rather cultural factors, for example demand sharing in Aboriginal Australia or bride price payments and formation of social alliances with other groups in Papua New Guinea, seem capable of shaping outcomes in either positive or negative ways. Further research is needed to increase our understanding of why similar social forms and practices can yield different outcomes across time and space.

\section{References}

Alexander, K. and Gilbert, S. 2010. Oil and Governance Report: A Case Study of Chad, Angola, Gabon, and Sao Tome é Principe, idasa: an African Democracy Institute. accessed 4 February 2013 $<$ http://www.idasa.org.za/our_products/books/book/oil_and_governance_report/>

Altman, J. C. and Pollack, D. P. 1998. Native title compensation: historic and policy perspectives for an effective and fair regime. Canberra: Centre for Aboriginal Economic Policy Research (CAEPR), Australian National University (ANU).

Altman, J. C. and Smith, D. E. 1994. The economic impact of mining moneys: The Narbarlek case, Western Arnhem Land. Canberra: CAEPR, ANU.

Bainton, N. A. 2010. The Lihir Destiny: Cultural Responses to Mining in Melanesia. Canberra: ANU E-Press.

Banks, G. 1996. "Compensation for Mining: Benefit or Time Bomb? The Porgera Gold Mine.” In Resources, Nations and Indigenous Peoples: Case Studies from Australasia, Melanesia and Southeast Asia, edited by R. Howitt, J. Connell and P. Hirsch, 223-35. Sydney: Oxford University Press.

Banks, G. 1999. "Gardens and wontoks.” In Dilemmas of development: the social and economic impact of the Porgera gold mine 1989-1994, edited by C. Filer, 160-90. Canberra: Asia Pacific Press.

Bauman, T. 2005. "Whose Benefits? Whose Rights? Negotiating Righst and Interests Amongst Indigenous Native Title Parties.” Land, Right, Laws: Issues of Native Title 3 (2): $1-11$.

Bauman, T. 2006. Final Report of the Indigenous Facilitation and Mediation Project July 2003-June 2006. Canberra: ATSIS.

Biersack, A. 1999. "Porgera - whence and whither?” In Dilemmas of development: the social and economic impact of the Porgera gold mine 1989-1994, edited by C. Filer, 260-79. Canberra: Asia Pacific Press.

Brunnschweiler, C. N. and Bulte, E.H. 2008. "Linking Natural Resources to Slow Growth and More Conflict.” Science (320): 616-617.

Bucuane, A. and Mulder, P. 2007. Exploring Natural Resources in Mozambique: will it be a blessing or a curse?, Maputo: Direçcão Nacional de Estudos e Análise de Politicas. 
Clark, A. J. 1999. Government Decentralization and Resource Rent Revenue Sharing: Issues and Policy. Honolulu: East-West Centre.

Collier, P. and Venebles, A. J. (eds). 2011. Plundered Nations? Successes and Failures in Natural Resource Extraction. Basingstoke, UK: Palgrave Macmillan,

Cornell, S. and Kalt J.P. 1995. "Where Does Economic Development Really Come From? Constitutional Rule Among the Contemporary Sioux and Apache.” Economic Inquiry (33): 402-26.

Cornell, S. and Kalt, J.P. 1998. Sovereignty and Nation-Building: The development challenge in Indian country today. Boston: Harvard University.

Cornell, S. and Kalt, J.P. 2010. American Indian Self-Determination: The Political Economy of a Policy that Works. John F. Kennedy School of Government, Harvard University. Accessed 16 June 2015 $<$ http://dash.harvard.edu/bitstream/handle/1/4553307/RWP10043_Cornell_Kalt.pdf?sequence $=1>$

Dodson, M. and Smith, D.E. 2003. Governance for sustainable development: Strategic issues and principles for Indigenous Australian communities. Canberra: CAEPR, ANU.

Eggert, R. G. 2001. Mining and Economic Sustainability. London: International Institute for Environment and Development.

Filer, C. 1990. "The Bougainville Rebellion, the Mining Industry and the Process of Social Disintegration in Papua New Guinea." Canberra Anthropology 13: 1-39.

Filer, C. 1999. "Introduction.” In Dilemmas of development: the social and economic impact of the Porgera gold mine 1989-1994, edited by C. Filer, 1-18. Canberra: Asia Pacific Press.

Gibson MacDonald, G., Zoe, J.B. and Satterfield, T. 2014. "Reciprocity in the Canadian Dene Damond Minign Economy.” In Natural Resource Extraction and Indigenous Livelihoods: Development Challenges in an Era of Globalization, edited by E. Gilberthorpe and G. Hilson, 57-74. London: Ashgate Press.

Gilberthorpe, E. 2007. "Fasu Solidarity: A Case Study of Kin Networks, Land Tenure and Oil Extraction in Kutubu, Papua New Guinea.” American Anthropologist 109 (1): 1-12.

Gilberthorpe, E. 2013. "Community development in Ok Tedi, Papua New Guinea: the role of anthropology in the extractive industries." Community Development Journal 48 (3): 466-83.

Gilberthorpe, E. and Banks, G. 2012, "Development on whose terms? CSR discourse and social realities in Papua New Guinea's extractive industries sector.” Resources Policy 37 (2): 185-93.

Haley, N. and May, R. (eds). 2007. Conflict and Resource Development in the Southern Highlands of Papua New Guinea. Canberra: ANU E Press.

Haselip, J. 2011. "Transparency, consultation and conflict: Assessing the micro-level risks surrounding the drive to develop Peru"s Amazonian oil and gas resources.” Natural Resources Forum 35: 283-92

Hunt, J. 2005. “Getting institutions right for women - women’s leadership in the international arena.” Darwin: North Australia Research Unit Seminar Series, Darwin, 6 July.

Karl, T.K. 1997. The Paradox of Plenty: Oil Booms and Petro-States. Berkeley: University of California Press.

Kesteven, S. 1984. "Money.” In Aborigines and Uranium: Consolidated Report to the Minister for Aboriginal Affairs on the Social Impact of Uranium Mining on the Aborigines of the Northern Territory, 134-49. Canberra: Australian Government Printing Services. 
Levitus, R. 1991. "The Boundaries of Gagudju Association Membership: Anthropology, Law and Public Policy.” In Mining and Indigenous Peoples in Australasia, edited by J. Connell and R. Howitt, 153-68. Sydney: Sydney University Press.

Levitus, R. 2005. "Land Rights and Land Economies: The Gagudju Association and the Mirage of Collective Self-Determination.” In Culture, Economy and Governance in Aboriginal Australia, edited by D. Austin-Broos and G. Macdonald, 29-39. Sydney: University of Sydney Press.

Levitus, R. 2009. “Aboriginal organizations and development: The structural context.” In Power, Culture, Economy: Indigenous Australians and Mining, edited by J. Altman and D. Martin, 73-98. Canberra: CAEPR, ANU.

Macintyre, M and Foale, S 2007), "Politicized Ecology: Local Responses to Mining in Papua New Guinea." Oceania 74 (3): 231-51.

Mantziaris, C. and Martin, D. 2000. Native Title Corporations: a legal and anthropological analysis. Sydney: The Federation Press.

Martin D. F. and Finlayson, J. D. 1996. Linking Accountability and self-determination in Aboriginal organisations. Canberra: CAEPR, ANU.

Mehlun, H., Moene, K. and Torvik, R. 2006. "Institutions and the Resource Curse.” Economic Journal 116: 1-20.

O’Faircheallaigh, C. 1990. “The Bougainville Crisis: Implications for Papua New Guinea and Australia.” Policy Organisation and Society, 1: 30-35.

O’Faircheallaigh, C. 1991. "Uranium Policy and the Economy.” Current Affairs Bulletin 68 (3): 4-11.

O’Faircheallaigh, C. 2002. A New Approach to Policy Evaluation: Mining and Indigenous People. London: Ashgate Press.

O’Faircheallaigh, C. 2010. “Aboriginal Investment Funds in Australia.” In The Political Economy of Sovereign Wealth Funds, edited by Xu Yi-chong and Gawdat Bahgat, 157-76. London: Palgrave Macmillan.

Pegg, S. 2006. “Mining and poverty reduction: Transforming rhetoric into reality.” Journal of Cleaner Production 14: 376-87.

Peterson, N. 1997. "Demand Sharing: Sociobiology and the Pressure for generosity among Foragers?.” In Scholar and Sceptic: Australian Aboriginal Studies in Honour of LR Hiatt, edited by F. Merlan, J. Morton and A. Rumsey, 171-90. Canberra: Aboriginal Studies Press.

Robinson, J. A., Torvik, R. and Verdier, T. 2006. "Political foundations of the resource curse” Journal of Development Economics 79: 447-68.

Ross, M. L. 1999. “The Political Economy of the Resource Curse.” World Politics 51: 297322.

Sachs, J. D. and Warner, A. M. 1997. Natural Resources Abundance and Economic Growth. Cambridge, MA: Harvard University Press.

Sandbu, M. E. 2006, "Natural Wealth Accounts: A Proposal for Alleviating the Natural Resource Curse.” World Development 34 (7): 1153-70.

Siakway, P. 2017. "Are natural resource windfalls a blessing or a curse in democratic setting”. Resources Policy 52: 122-33.

Sillitoe, P. and Wilson, R. A. 2003. "Playing on the Pacific Ring of Fire: Negotiation and Knowledge in Mining in Papua New Guinea.” In Negotiating Knowledge: Power and Identity in Development, edited by J. Pottier, A. Bicker and P. Sillitoe, 241-72. London: Pluto Press.

Sovacool, B. K. 2010. "The political economy of oil and gas in Southeast Asia: heading towards the natural resource curse?.” The Pacific Review 23 (2): 225-59.

Stanner, W.E.H. 2009. The Dreaming and Other Essays. Collingwood: Black Inc Agenda. 
Stevens, P. 2003. "Resource Impact - Curse or Blessing: A Literature Survey.” Dundee: Centre for Energy, Petroleum and Mineral Law and Policy, University of Dundee. Accessed 4 February 2013.

$<$ http://www.dundee.ac.uk/cepmlp/journal/html/Vol13/vol13-14.html $>$

Sullivan P. 2007. Indigenous Governance: The Harvard Project, Australian Aboriginal

Organisations and Cultural Subsidiarity. Alice Springs: Desert Knowledge CRC.

Trigger, D. 2005. "Mining Projects in remote Australia: sites for the articulation and contesting of economic and cultural futures." In Culture, Economy and Governance in Aboriginal Australia, edited by D. Austin-Broos and G. Macdonald, 41-62. Sydney: University of Sydney Press.

York, G. 1990. The Dispossessed: Life and Death in Native Canada. Vintage U.K.: London. Williams, A. (2011), "Shining a Light on the Resource Curse: An Empirical Analysis of the Relationship between Natural Resources, Transparency and Economic Growth.” World Development 39 (4): 490-505.

Notes

${ }^{1}$ In earlier work (O’Faircheallaigh 1991) I have shown, for instance, how payments to Aboriginal peoples accounted for a very large proportion of the share of income generated by uranium mining which was retained in Australia's Northern Territory.

${ }^{2}$ Under the Aboriginal Land Rights (Northern Territory) Act 1976 the Northern Territory is divided between regional Aboriginal land councils which have statutory responsibilities in relation to the allocation and use of royalty payments. 